\title{
Effects of Forest Fire on Leaf Litter Decomposition of Two Dominant Species (Tristaniopsis obovata and Calophyllum pulcherrimum) in a Heath Forest of South Kalimantan
}

\author{
Joeni Setijo RAHAJOE ${ }^{1)}$ \& Takashi KoHYAMA ${ }^{2)}$ \\ ${ }^{1)}$ Present address: Herbarium Bogoriense, Research Center for Biology — The Indonesian Institute of Sciences. Jl. \\ Juanda No.22, Bogor 16122 Indonesia/ JOENISR@indo.net.id \\ ${ }^{2)}$ Graduate School of Environmental Earth Science, Hokkaido University Sapporo 060-0810 Japan.
}

\begin{abstract}
In order to determine the effects of frequent forest fire on the decomposition process, two dominant species of heath forests were studied: T. obovata and C. pulcherrimum. During a period of two years, it was observed that $T$. obovata decomposed more rapidly with higher nutrient release than $C$. pulcherrimum in intact and post-fire stands. The decomposition rates of the two species were higher in the intact stand than in the post-fire stand. $\mathrm{C} / \mathrm{N}$ ratio dynamics and nitrogen release were determined showing that $T$. obovata rapidly released nutrients and $C$. pulcherrimum retained nutrients. The results suggest that forest fire did not change the nutrient release pattern of these two dominant species, but did slow the decomposition rate and, consequently, affected the rate of nitrogen release.
\end{abstract}

Key words: decomposition rate, forest fire, intact heath forest, post-fire stand.

\section{INTRODUCTION}

At the end of the 1997 dry season, which was exceptionally dry due to ENSO, the biggest fires of the year broke out over almost all forest types in Kalimantan and Sumatra Island. The fires emitted smoke into the air blanketing the entire region in haze, reaching as far as Thailand, Philippines, Malaysia and Singapore. Forest fires have enormous impacts on tropical forest ecosystems and biodiversity (Barber \& Schweithelm, 2000). The estimated area of damage by fires during 1997-1998 in Kalimantan was 75,000 ha of peat swamp forest, 2,375,000 ha of lowland forest, 2,829,000 ha of agricultural land, 116,000 ha of timber plantation, 55,000 ha of estate crops and 375,000 ha of dry scrub \& grass land, with a total damage of 6,500,000 ha (RePPProT 1985). Frequent forest fires have occurred for the past twenty years and repeated burning cycles have completely transformed forests into grasslands or scrublands. As was reported by Abdulhadi et al. (1998), repeated burning has created large areas of unproductive grasslands in place of original dipterocarp forests. In a mixed dipterocarp forest in East Kalimantan after a forest fire about $90 \%$ of 240 trees in a 1.6-ha plot died (Whitmore, 1984). In a heath forest, floristic composition in burnt and un-burnt plots was quite similar, having $77 \%$ similarity about 1.5 years after the fire (Abdulhadi et al. 1998).

There is ample information on the effects of forest fire on vegetation dynamics, forest structure and species composition (Cochrane \& Schulze 1999; Driscoll et al. 1999; Hjerpe et al. 2001). With regard to the effects of fire on nutrient dynamics in lowland tropical forests, the work of Kutiel \& Inbar (1983), 
Gillon \& Rap (1989) and Driscoll et al. (1999) can be cited. However, little information is available on the impact of forest fire on the decomposition process in heath forests, the typical forest type in Kalimantan. This information is crucial, as the nutrient released from decomposing litter is the major nutrient source for plant growth (Lamber et al., 1998), and furthermore, during forest fires the soil nutrient status changes, most notably, nitrogen loss increases (Aerts \& Chapin 2000). The effects of fire on soil erosion, light intensity, pH, the quality of soil organic matter (Pietikäinen \& Fritze 1996; Flannigan et al. 2000), surface runoff, soil moisture and temperature (Viro 1974; Cass et al. 1984) are subjects of much concern to studies on the effect of burning on the decomposition processes. The loss of organic matter from the soil surface after a forest fire also exposes the soil to direct sunlight, decreasing the activity of soil microorganisms, because of high temperatures (Viro 1974; Cass et al. 1984; Pietikäinen \& Fritze 1996; Bazzaz 2000; Flannigan et al. 2000). The decomposition process is also dependent on such climatic factor as humidity and temperature (Köchy \& Wilson 1997), as well as soil organisms (Gallardo \& Merino 1993; Swift 1995). Therefore changes in these factors due to forest fire will affect the decomposition process. The objectives of this research were to examine 1) the decomposition rates of two dominant species in a heath forest in Central Kalimantan, and 2) the effects of forest fire on nitrogen release and $\mathrm{C} / \mathrm{N}$ ratio dynamics during the decomposition process.

\section{METHODS}

\section{Study site}

The study site was in Lahei village, located $40 \mathrm{~m}$ above sea level, and $1^{\circ} 55^{\prime} \mathrm{S}$ in latitude, $114^{\circ} 10^{\prime} \mathrm{E}$ in longitude. Most of the area is covered with heath forest, with scattered patches of peat swamp forest. The annual precipitation at Palangkaraya is about $2800 \mathrm{~mm}$ (1993 to 1999 average), but is approximately $2970 \mathrm{~mm}$ when the data from the El Niño year (1997) are excluded. Monthly rainfall is over $100 \mathrm{~mm}$ in most months, and below $100 \mathrm{~mm}$ during the few months of the dry season. The annual mean temperature varies between $26-28^{\circ} \mathrm{C}$. Heath forests in Borneo occur on poor sandy soils, strongly podzolized or even seasonally waterlogged soils, to form humus podzols, humus iron podzols, and ground water humus podzols (Specht 1979). Soil in heath forests is very acidic and poor in nitrogen content (Moran et al. 2000) and levels of all soil nutrients in the heath forest at the Lahei site were low to very low (in terms of FAO criteria) in the overall profile (Djuwansah 2000).

The heath forest is dominated by Calophyllum pulcherrimum Wall. ex Choisy, Tristaniopsis obovata (Benn.) Wilson et Waterhouse, and Palaquium leiocarpum Boerl. The forest mainly consists of small trees (the maximum trunk diameter was $69.7 \mathrm{~cm}$ ). The tallest tree is $37 \mathrm{~m}$ high and the number of species of trees with more than a $15 \mathrm{~cm}$ trunk girth is 122 . The tree density of the heath forest is 1982 ha $^{-1}$ and basal area is $27.6 \mathrm{~m}^{2} \mathrm{ha}^{-1}$ (Suzuki et al. 1998; Miyamoto et al., 2002). Total above-ground biomass is $188.23 \pm 3.9 \mathrm{t} \mathrm{ha}^{-1}$ (Miyamoto 2002). The soil temperature of the heath forest was around 25 to $30^{\circ} \mathrm{C}$ throughout the study period. An intact forest stand and a post-fire stand (after the forest fire in 1997) of heath forest were selected as study sites. The distance between these two stands was about $2 \mathrm{~km}$. The post-fire stand was dominated by Imperata cylindrica. Burnt stems and standing dead trees were scattered on the stand floor. The period of the study was February 1998-March 2000. In the dry season of 2002 , the intact stand research site was destroyed by forest fire. 


\section{Field experiments}

In the heath forest a 1-ha intact plot was established (Suzuki et al., 1998; Miyamoto et al., 2002). The trees of two dominant species (T. obovata and C. pulcherrimum) from outside the 1-ha plot were cut to collect their leaves and stems. Collected leaves were dried and $100 \mathrm{~g}$ leaves filled each litter bag. One set of three stem sizes for each dominant species (small $=2-3 \mathrm{~cm}$, medium $=3-4 \mathrm{~cm}$ and large $=4-5$ $\mathrm{cm}$, stem diameter) was put in the litter bags. 428 litter bags (224 leaf and stem) were placed in the 1-ha intact stand and the post-fire stand systematically and samples were collected monthly. Nitrogen and carbon content was estimated by an automatic C-N analyzer (Vario EL, Elementar Analysensysteme GmbH, Hanau, Germany).

\section{Statistical analysis}

The decomposition constant $k$ was estimated by fitting the exponential model $W(\mathrm{t})=\mathrm{W}_{\mathrm{o}} \mathrm{e}^{\mathrm{kt}}$, where $\mathrm{W}_{\mathrm{o}}$ is initial mass, $W$ represents the remaining mass of the litter, $t$ is time, and $k$ is the decomposition rate (Olson, 1963). ANOVA was used to examine the differences among species for mass and nutrient content in the intact and post-fire stands. A Scheffe test was used in an a posteriori comparison to examine significant differences among means $(p<0.05)$.

\section{RESULTS}

\section{Decomposition rate of leaf and stem}

Significantly different rates of decomposition were found between T. obovata and C. pulcherrimum ( $p<$ $0.001)$ and between the locations $(p<0.05)$ during the duration of the experiment. The rate of decomposition was higher in the intact stand than in the post-fire stand (Fig. 1). Leaf decomposition rate was higher for T. obovata $\left(k=1.3 \mathrm{y}^{-1}\right)$ than $C$. pulcherrimum $\left(k=0.5 \mathrm{y}^{-1}\right)$ in the intact stand, and also in the post-fire stand the rate was higher for T. obovata $\left(k=0.8 \mathrm{y}^{-1}\right)$ than $C$. pulcherrimum $(k=0.2$ $\left.\mathrm{y}^{-1}\right)$. These results suggest that forest fires decrease the decomposition rate of these dominant species.

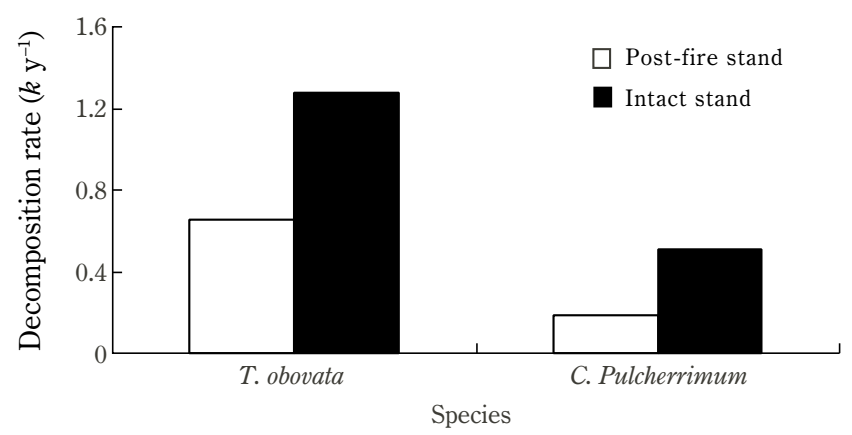

Fig. 1. Comparison of leaf decomposition rate of T. obovata and C. pulcherrimum in an intact and post-fire stand in a heath forest.

The rate of stem decomposition of the two species was not significantly different between the locations, species or diameter classes (Fig. 2). Although it was not statistically significant, the 
decomposition rate of $T$. obovata was faster in the post-fire stand than the intact stand, while $C$. pulcherrimum showed no specific pattern.

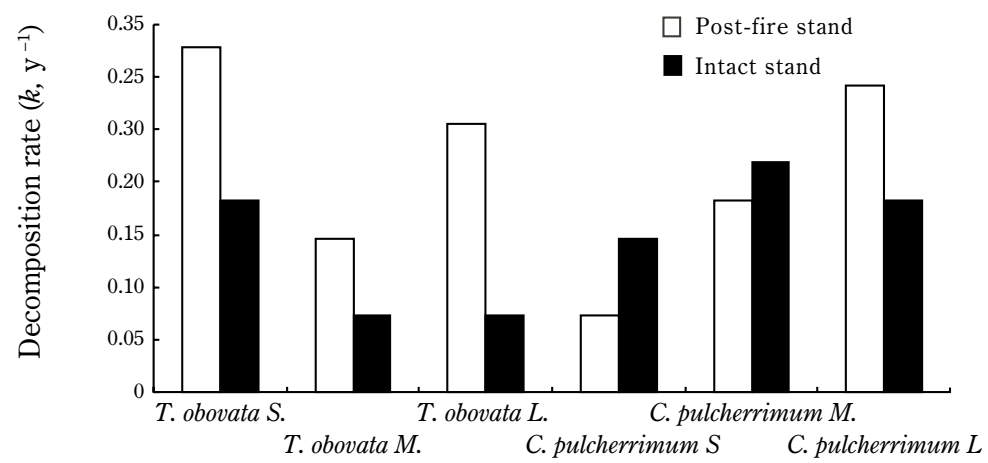

Fig. 2. The decomposition rate of stems of the dominant species in intact and post-fire stands. $\mathrm{S}=$ small $(2-3 \mathrm{~cm}), \mathrm{M}=$ medium $(3-4 \mathrm{~cm})$ and $\mathrm{L}=$ large $(4-5 \mathrm{~cm})$, in stem diameter.

The decomposition of the remaining leaves in the post-fire stand fluctuated markedly during the study period. The decomposition of the remaining leaves was not constant during the first year, and thereafter during the second year, decomposed slowly. In the intact stand, the remaining leaves decomposed throughout the study period (Fig. 3). At the end of the experiment the lowest amount of remaining leaves was that of $T$. obovata, $12 \%$ and $15 \%$ of the initial mass of leaves in intact and post-fire stands, respectively. For $C$. pulcherrimum the remaining mass of leaves was $40 \%$ and $77 \%$ in the intact and post-fire stands, respectively.

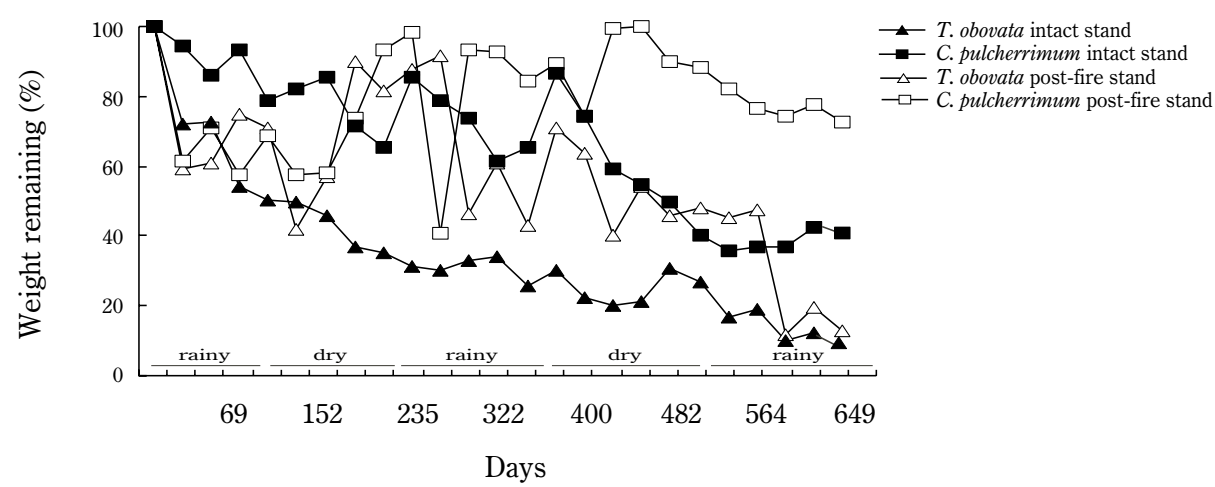

Fig. 3. Remaining mass (\%) of leaf litter T. obovata and $C$. pulcherrimum in intact and post-fire stands.

\section{$\mathrm{C}, \mathrm{N}$ and $\mathrm{C} / \mathrm{N}$ ratio dynamics during the decomposition process}

Decreasing carbon content was significantly different between the stands for both species $(p<0.001)$, and a decrease in carbon content was seen higher in the post-fire stand than in the intact stand (Fig. 4). 
The nitrogen content of both species increased during the decomposition process in the intact stand and in the post-fire stand, but was lower in the post-fire stand than in the intact stand (Fig. 5). The nitrogen content of $T$. obovata was higher than that of $C$. pulcherrimum in the intact and post-fire stand, indicating that more nutrients from $T$. obovata were released, and a decrease in remaining leaf mass (Fig. 3) was followed by an increase in nitrogen content (Aber \& Mellilo 1982; Anderson et al. 1983; McClaugherty et al., 1985). The release of nitrogen of $T$. obovata was from 442.9 to $197.7 \mathrm{mg}$ at the first year of decomposition process, and that was decreased to $37.6 \mathrm{mg}$ at the end of study period (Fig. 5). The nitrogen release of $C$. pulcherrimum was from 338.6 to $164.8 \mathrm{mg}$, in the post-fire stand. Nitrogen was release in the intact stand from the two species, even though their $\mathrm{C} / \mathrm{N}$ ratio was above 40 , from 442.9 to 129.8 and 338.6 to $253.5 \mathrm{mg}$, for T. obovata and C. pulcherrimum respectively.
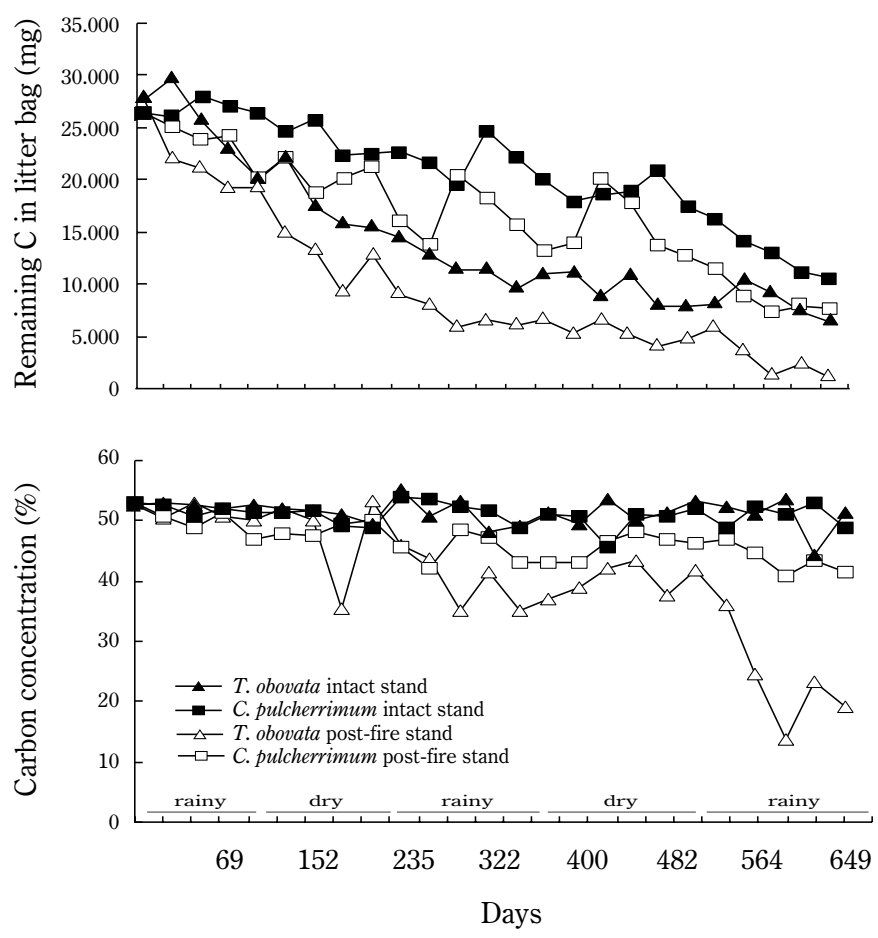

Fig. 4. Changes in carbon content and mass of decomposing litter during the decomposition period in intact and post-fire stands.

The $\mathrm{C} / \mathrm{N}$ ratio of leaf litter from the two dominant species decreased in both study sites (Fig. 6). The $\mathrm{C} / \mathrm{N}$ ratio of $T$. obovata decreased from 62 to 34 (in the intact stand) and to 31 (in the post-fire stand) during the first year and at the end of study decreased further to 31 (in the intact stand) and 27 (in the post-fire stand). The $\mathrm{C} / \mathrm{N}$ ratio of $C$. pulcherrimum decreased from 77 to 45 in the intact stand and 46 in the post-fire stand, during the 2-yr period. Nitrogen mineralization in tropical forests occurs at a $\mathrm{C} / \mathrm{N}$ ratio of approximately $30-40$, thus nitrogen mobilization of $T$. obovata was correctly predicted during the second year, to have a $\mathrm{C} / \mathrm{N}$ ratio lower than 34 followed by increased nitrogen content (Fig. 
5). For C. pulcherrimum no net mineralization occurred until the end of the experiment in the intact and post-fire stands when the $\mathrm{C} / \mathrm{N}$ ratio was higher than 40 .
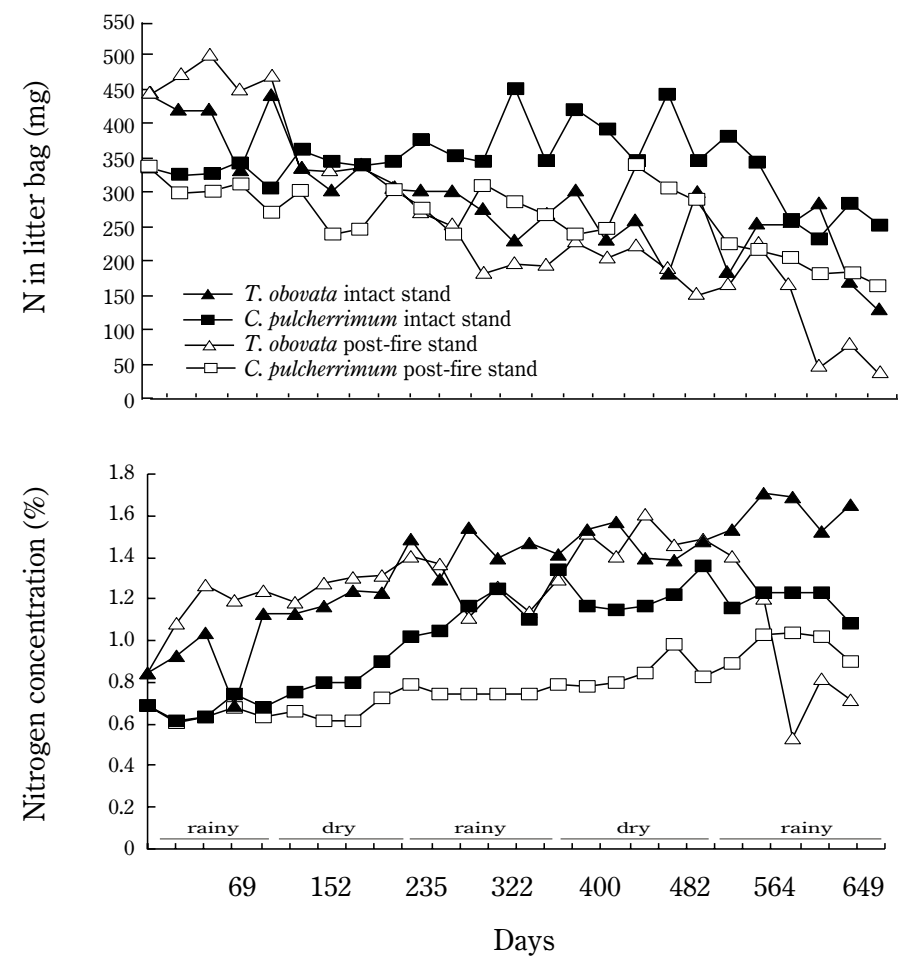

Fig. 5. Changes in nitrogen remaining and content of decomposing litter during the decomposition period in intact and post-fire stands.

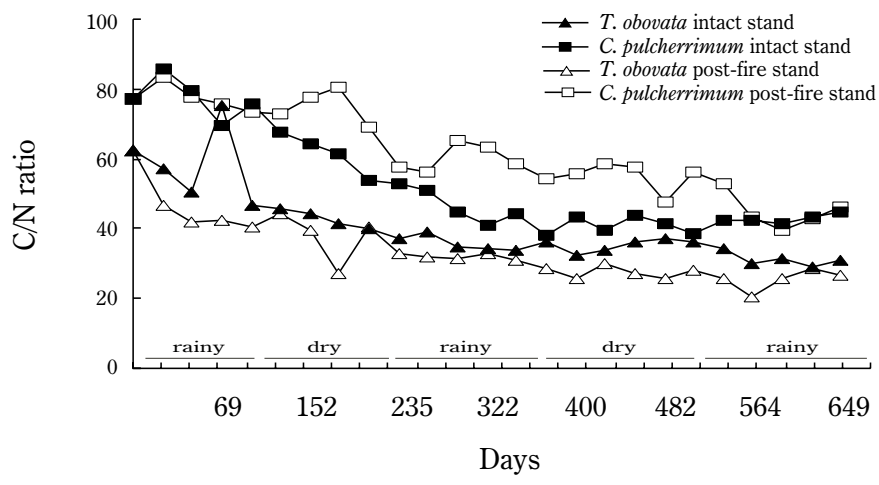

Fig. 6. Changes in $\mathrm{C} / \mathrm{N}$ ratio of leaf litter $T$. obovata and $C$. pulcherrimum during the decomposition period in intact and post-fire stands. 


\section{DISCUSSION}

\section{Decomposition rate}

Leaf litter of $T$. obovata decomposed faster than that of $C$. pulcherrimum, due to the lower initial lignin content of T. obovata (28\%) than C. pulcherrimum (49\%) (Rahajoe \& Kohyama submitted). Plant material with higher lignin content decomposes more slowly than those with lower initial lignin content (Berg \& Staaf 1981; Berendse et al. 1987; 1989; Aerts 1997) or lower initial C/N ratio (Wieder \& Lang 1982). Leaf litter of $T$. obovata was decomposed rapidly during the first rainy season. The loss of leaf mass is affected by leaching via tropical rainfall and is related to the leaching of soluble organic materials and inorganic compounds (Berg \& Staaf 1980; Laskowski et al. 1995; Swift 1995). Resistant materials have a slower loss rate (Swift 1995).

The leaf decomposition rate of these two dominant species was significantly higher in the intact stand than in the post-fire stand, due to microclimatic changes on the forest floor caused by forest fire (Viro 1974; Cass et al. 1984; Flannigan et al. 2000). During a forest fire, the subsoil burns and only the A2 or A-E horizon remains (Djuwansah 1999). This horizon is white sand (quartz sand), which is nutrient poor, with a low water holding capacity (Viro 1974) and few soil materials (Cass et al. 1984; Dumontet et al. 1996). Forest fire exposes the soil surface to direct sunlight, accelerating soil desiccation (Pietikäinen \& Fritze 1996; Zhang \& Zak 1999; Bazzaz 2000). The combined factors of low soil moisture and high light intensity are unsuitable for the activity of primary decomposers (Zhank \& Zak 1999), especially bacteria and fungi, and inhibition of microbial activity, resulting in slower decomposition rates in post-fire stands.

The change in carbon content with decomposition was significantly different between stands and a decrease in carbon content was seen only in the post-fire stand (Fig. 4). It is suggested that carbon-rich components of leaf litter, such as lignin, are selectively attacked by decomposers, thus indicating that forest fire changes soil microflora.

\section{Nitrogen release and $\mathrm{C} / \mathrm{N}$ ratio during the decomposition process}

The increase in nitrogen content during decomposition found in this study is likely attributable to the immobilization of nutrients by bacteria and fungi colonized in the residual litter in intact and post-fire stands (Chale 1993; Odum et al. 1979). The rate of decomposition was lower in the post-fire stand than in the intact stand, and this low decomposition rate causes the lower nitrogen content in the post-fire stand than in the intact heath stand (Menaut et al. 1993). The opening up of areas by forest fire facilitates nitrogen loss by volatilization (Jordan 1985; Menaut et al. 1993; Aerts \& Chapin 2000). Therefore the increase of nitrogen content of $C$. pulcherrimum and T. obovata was small and the nitrogen released from decomposing litter was easily leached by soil runoff via soil erosion (Cass et al. 1984; Jordan 1985; Menaut et al. 1993). This information suggests that nitrogen is less available in postfire stands than in intact stands.

The dominant species in heath and peat swamp forests have their own patterns of releasing nitrogen to the forest floor (Rahajoe \& Kohyama submitted). Torreta \& Takeda (1999) classified the dominant species in Thailand as nutrient retention species (with a $\mathrm{C} / \mathrm{N}$ ratio above 40) and rapid nutrient releasing species (with a $\mathrm{C} / \mathrm{N}$ ratio about 30-40). In this study, C. pulcherrimum showed no net mineralization until the end of the experiment and nitrogen was immobilized in leaf litter. Species such 
as $C$. pulcherrimum are important for the retention of nitrogen in the forest floor sub-systems, while $T$. obovata rapidly released nitrogen from decomposing litter. This study found that the two dominant species in the intact and the post-fire stands in central Kalimantan have different patterns, but similar responses to fire: $T$. obovata is characterized by rapid nutrient release and $C$. pulcherrimum by nutrient retention, suggesting that forest fire did not change the nutrient release pattern of these two dominant species, but did lower the decomposition rate and consequently affected the rate of nitrogen release for both species.

ACKNOWLEDGMENTS We thank Suwido H. Limin, M Sc. his cooperation during our research in Palangkaraya. We also thank Palangkaraya University students under Mr. Suwido's guidance: Agung D. Seventree, Nathalius, Kitso, Sylphanus and Yarden. We appreciate Aden Muhidin, Mohammad Amir and Arief for their field work assistance during the research. This research was supported by the Japan Society for the Promotion of Science (JSPS). We thank to Takashi B. Nishimura for critical reading of our earlier draft.

\section{REFERENCES}

Abdulhadi, R., Pertomihardjo, T., Adhikerana, A. S., Simbolon, H. and Budiman, A. 1998. A preliminary survey on the impact of forest fire on flora and fauna. In Tropical forest fire. Prevention, control, rehabilitation and trans-boundary issue. Proceeding International Cross Sectorial Forum on Forest Fire Management in South East Asia. National Development Planning Agency. Indonesia.

Aber, J.D. \& Melillo, J.M. 1982. Nitrogen immobilization in decaying hardwood leaf litter as a function of initial nitrogen and lignin content. Canadian Journal of Botany 60: 2263-2269.

Aerts, R. 1997. Climate, leaf litter chemical and leaf litter decomposition in terrestrial ecosystems; a triangular relationship. Oikos 79: 439-449.

Aerts, R. \& Chapin, F.S. 2000. The mineral nutrition of wild plants revisited: A re-evaluation of processes and patterns. In Fitter, A. H. \& Raffaeli, A. H. (eds.). Advances in Ecological Research. pp. 30: 1-67. Academic Press. UK.

Anderson, J.M., Proctor J. \& Vallack, H.W. 1983. Ecological studies in four contrasting lowland rain forest in Gunung Mulu National Park, Serawak. III. Decomposition processes and nutrient losses from leaf litter. Journal of Ecology 71: 503-527.

Barber, C. V. \& Schweithelm, J. 2000. Trial by fire: Forest fires and forestry policy in Indonesia's Era of crisis and reform. World Resources Institute. USA.

Berendse, F., Berg, B., \& Bosatta, E. 1987. The effect of lignin and nitrogen on the decomposition of litter in nutrient-poor ecosystems: A theoretical approach. Canadian Journal of Botany 65: 1111120.

Berendse, F. Bobbink, R. \& Rouwenhorst, G. 1989. A Comparative study on nutrient cycling in wet heathland ecosystems. II. Litter decomposition and nutrient mineralization. Oecologia 78: 338-348.

Berg, B. \& Staff, H. 1980. Decomposition rate and chemical changes of Scots pine needle litter, II. Influence of chemical composition. In Persson, T. (ed.). Structure and Function of Northern Coniferous Forest - An ecosystem Study. vol. 32, pp. 373-390. Ecol. Bull. Stockholm.

Cass, A., Savage, M.J. \& Wallis, F.M. 1984. The effect of fire on soil and microclimate. In Booysen, P. 
de V. and Taiton, N. M. (eds.). In Ecological effect of forest fire in South African ecosystems. SpringerVerlag. Berlin.

Cochrane, M.A. \& Schulze, M.D. 1999. Fire as a recurrent event in tropical forests of the eastern Amazon: Effect on forest structure, biomass, and species composition. Biotropica 31: 2-16.

Djuwansah, R. 2000. Some characteristics of tropical Podzol in Kalimantan. Proceedings of the International Symposium on: Tropical Peat Lands. Graduate School Environmental Earth Science Hokkaido University and Research and Development Center for Biology.

Driscoll, K.G. Arocena, J.M. \& Massicotte, H.B. 1999. Post-fire soil nitrogen and vegetation composition in Sub-Boreal sruce forests of British Colombia's central interior, Canada. Forest Ecology and Management 121: 227-237.

Dumontet, S., Dinel H., Scopa, A., Mazzatura, A. \& Saracino. 1996. Post-fire soil microbial biomass and nutrient content of a pine forest soil from a Dunal Mediterranean environment. Soil Biology \& Biochemistry 28: 1467-1475.

Flannigan, M.D., Stocks, B.J., Wotton, B.M. 2000. Climate change and forest fires. The Science of the Total Environment 262: 221-229.

Gallardo, A. \& Merino, J. 1993. Leaf decomposition in two Mediterranean ecosystems of Southwest Spain: influence of substrate quality. Ecology 74: 152-161.

Gillon, D. \& Rapp, M. 1989. Nutrient losses during a winter low-intensity prescribed fire in a Mediterranean forest. Plant Soil 120: 69-77.

Hjerpe, J. Hedenas, H \& Elmqvist, T. 2001. Tropical rain forest recovery from Cyclon damage and fire in Samoa. Biotropica 33: 249-259.

Jordan, C.F. 1985. Nutrient cycling in tropical forest ecosystems. John Wiley \& Sons. New York. 179 pp.

Köchy, M. \& Wilson, S.D. 1997. Litter decomposition and Nitrogen dynamics in Aspen forest and mixed-grass prairie. Ecology 78: 732-739.

Kutiel, P. \& Inbar, M. 1983. Fire impacts on soil nutrient and soil erosion in a Mediterranean pine forest plantation. Catena 20: 11-24.

Lambers, H.F., Chapin III, S. \& Pons. T.L. 1998. Plant physiological ecology. Springer. New York. p. 540.

Laskowski, R. Nisklinska, M. \& Mayanski, M. 1995. The dynamic of chemical elements in forest litter. Ecology 76: 1393-1406.

Menaut, J.C., Abbadie, L. \& Vitousek, P.M. 1993. Nutrient and organic matter dynamics in tropical ecosystems. In Crutzen P.J. \& Goldammer, J. G. (eds.). Fire in the environment; The ecological, Atmospheric, and climatic Importance of Vegetation Fires. pp. 215-231John Willey \& Sons. Chichester.

McClaugherty, C.A., Pastor, J., Aber. J.D. \& Mellilo, J.M. 1985. Forest litter decomposition in relation to soil Nitrogen dynamics and litter quality. Ecology 66: 266-275.

Miyamoto, K. 2000. Convergence and differentiation in tree architecture among co-occuring species in tropical heath forest. Doctoral dissertation - Hokkaido University. Sapporo. 85 pp.

Miyamoto, K., Suzuki, E. Kohyama, T., Seino, T., Mirmanto, E \& Simbolon H. 2002. Habitat differentiation among tree species with small-scale variation of humus depth and topography in tropical heath forest of Central Kalimantan, Indonesia. Journal of Tropical Ecology. 19: 1-13.

Moran, J.A., Barker, M.G., Moran, A.J. \& Becker, P. 2000. A comparison of the soil water, nutrient status, and litterfall characteristics of tropical heath and mixed-dipterocarp forest sites in Brunei. 
Biotropica 32: 2-13.

Olson, J.S. 1963. Energy storage and the balance of procedures and decomposers in ecological systems. Ecology 44: 322 - 331.

Pietikäinen, J. \& Fritze, H. 1996. Microbial bimass and activity in the humus layer following burning short term effects of two different fires. Canadian Journal Forest Research 23: 1275-1285.

Rahajoe, J.S. \& Kohyama, T. Seasonal variation in production and decomposition of leaf litter for dominant tree species in heath and peat swamp forest in southern Borneo. Submitted paper MS JTE 02/145.

RePPProT 1985. Land Systems and Land Suitability Series at 1: 250000 scale. Accompanying maps of review of phase 1B result, Central Kalimantan. Regional physical planning program for transmigration. UK Overseas Development Administration and Directorate Bina Program. Ministry of Transmigration. Jakarta.

Specht, R.L. \& Womersly, J.S. 1979. Heath lands and related shurblands. In R.L. Specht (ed). Ecosystems of the world 9A. pp 321-338. Elsevier Scientific Publishing company. New York.

Swift, M.J. 1995. Introduction: Soil biology and fertility in the tropics. In Reddy, M. V. (ed). In soil organism and litter decomposition in the tropics. pp 1-12. Oxford \& IBH publisher. India.

Suzuki, E., Kohyama, T. Simbolon, H. Akira, H. Shiro, T. Nishimura, T. Seino. T. 1999. Vegetation of kerangas (heath) and peat swamp forests in Lahei, Central Kalimantan. Annual report of Environmental Conservation and Land Use Management of Wetland Ecosystem in South Asia. Core University Program between Hokkaido University, Japan and R \& D Center of Biology, LIPI Indonesia. Sponsored by Japan Society for the Promotion Science.

Torreta, N.K, \& Takeda. H. 1999. Carbon and nitrogen dynamics of decomposing leaf litter in a tropical hill evergreen forest. European Journal Soil Biology. 35: 57-63.

Viro, P.J.1974. Effect of forest fire on soil. In Kozlowski, T. T. \& Ahlgren, C. E. (eds.). Fire and Ecosystems. pp. 8-45.Academic Press. London.

Wieder, R.K., \& Lang, G.E., 1982. A critique of the analytical methods used in examining decomposition data obtained from litter bags. Ecology 63: 1636-1642.

Whitmore, T.C. 1984. Tropical rain forest of the Far East. $2^{\text {nd }}$ edition. Clarendon Press Oxford University Press.

Zang, Q. \& Zak. J.C. 1995. Effect of gap size on litter decomposition and microbial activity in subtropical forest. Ecology 76: 2196-2204.

Received Nov. 13, 2002

Accepted Dec. 13, 2002 